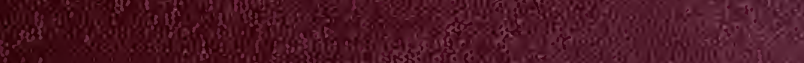

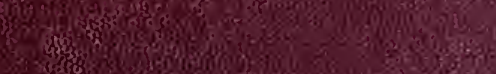

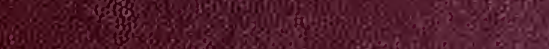
r. 4 . n. 



\section{Historic, archived document}

Do not assume content reflects current scientific knowledge, policies, or practices. 



\section{U. S. DEPARTMENT OF AGRICULTURE,} BUREAU OT ENTOMOLOGY-CIRCULAR NO. 152. L. O. HOWARD, Entomologist and Chief of Bureau.

\section{THE RICE WATER-WEEVIL AND METHODS FOR ITS CONTROL.}

BY

E. S. TUCKER,

Entomological Assistant. 


\section{BUREAU OF ENTOJIOLOGY.}

L. O. Howard, Entomologist and Chicf of Burcau.

C. L. Marlatt, Entomologist and Acting Chief in Absence of Chicf.

R. S. Clifton, Exccutive Assistant.

W. F. TAStet, Chicf Clcrl.

F. H. Chittenden, in charge of truck crop and storcd product inscet investigations.

A. D. Hopkins, in charge of forest insect investigations.

W. D. Hunter, in charge of southern ficld crop insect investigations.

F. M. WeBster, in charge of cereal and forage inscet invesligutions.

A. L. Quantance, in charge of deciruous fruit inscet investigationis.

E. F. Phillips, in charge of bec culture.

D. M. Rogens, in charge of preventing sprcad of moths, ficld work.

Rolia P. CuRrie, in charge of cditorial work.

MABEL ColcoRD, in charge of library.

\section{Southern Field Crop Insect Investigations.}

W. D. Hunter, in charge.

IV. D. Pierce, G. D. Simtit, J. D. Mitchell, Harry Pinkus, B. R. Coad, R. W. Moreland, engaged in cotton-boll wecril investigations.

F. C. Bishopr, A. H. Jennivgs, H. P. Wood, W. T. King, engaged in tick investigations.

A. C. Morgan, G. A. Runner, S. E. Crumb, D. C. Parman, engaged in tobacco insect investigations.

T. E. Holloway, E. R. Barber, cngaged in sugar cane insect investigations.

E. A. McGregor, W. A. Thomas, engaged in red spider and other cotton insect investigations.

J. L. WEBB, cugaged in rice insect investigations.

I. A. Cooley, U. L. Tan Dine, A. F. Conradi, C. C. Kórumbianr, collaborators. 


\title{
United States Department of Agriculture,
}

BUREAU OF ENTOMOLOGY.

I. O. HOWARD, Entomologist and Chief of Bureau.

\section{THE RICE WATER-WEEVIL AND METHODS FOR ITS CONTROL.}

\author{
(Lissorhoptrus simplex Say.) \\ By E. S. TuCKER, \\ Entomological Assistant.
}

ECONOMIC IMPORTANCE.

The most serious insect enemy of growing rice in the Southern States is the rice water-weevil (Lissorhoptmis simplex Say) (fig. 1). When in its larval stage, the insect is known to rice growers as the "rice root-maggot." The larræ feed on the roots of rice plants, and the adult weevils cause some harm by feeding on rice leaves.

Owing to the extensive growing of rice in sections of Louisiana, Texas, and Arkansas within recent years, the weevil has found very favorable conditions in the rice fields for its multiplication in proportion to the increase of the acreage and to the number of years in which rice has been grown in any section. The development of definite rice-growing areas in these States has naturally resulted in particular centers of high infestation by the weevil. Rice growing has consequently been attended by great damage to the crops on account of the insect's attacks.

The amount of loss that is occasioned by the attacks is difficult to estimate, as the reduction of yield has been variously reckoned in different localities. Since all fields are not affected alike and different portions or spots of a field are apt to suffer the severest injuries, although the plants seldom fail outright, the growers differ much in their opinions of the extent of damage which they sustain, but all agree in the declaration that it is considerable. General statements of the shortage of production include a report by a grower at Beaumont, Tex., who placed his loss as low as 1 per cent; but the attacks in some fields at Stuttgart, Ark., have been severe enough to cut down the yield as much as 75 per cent. 

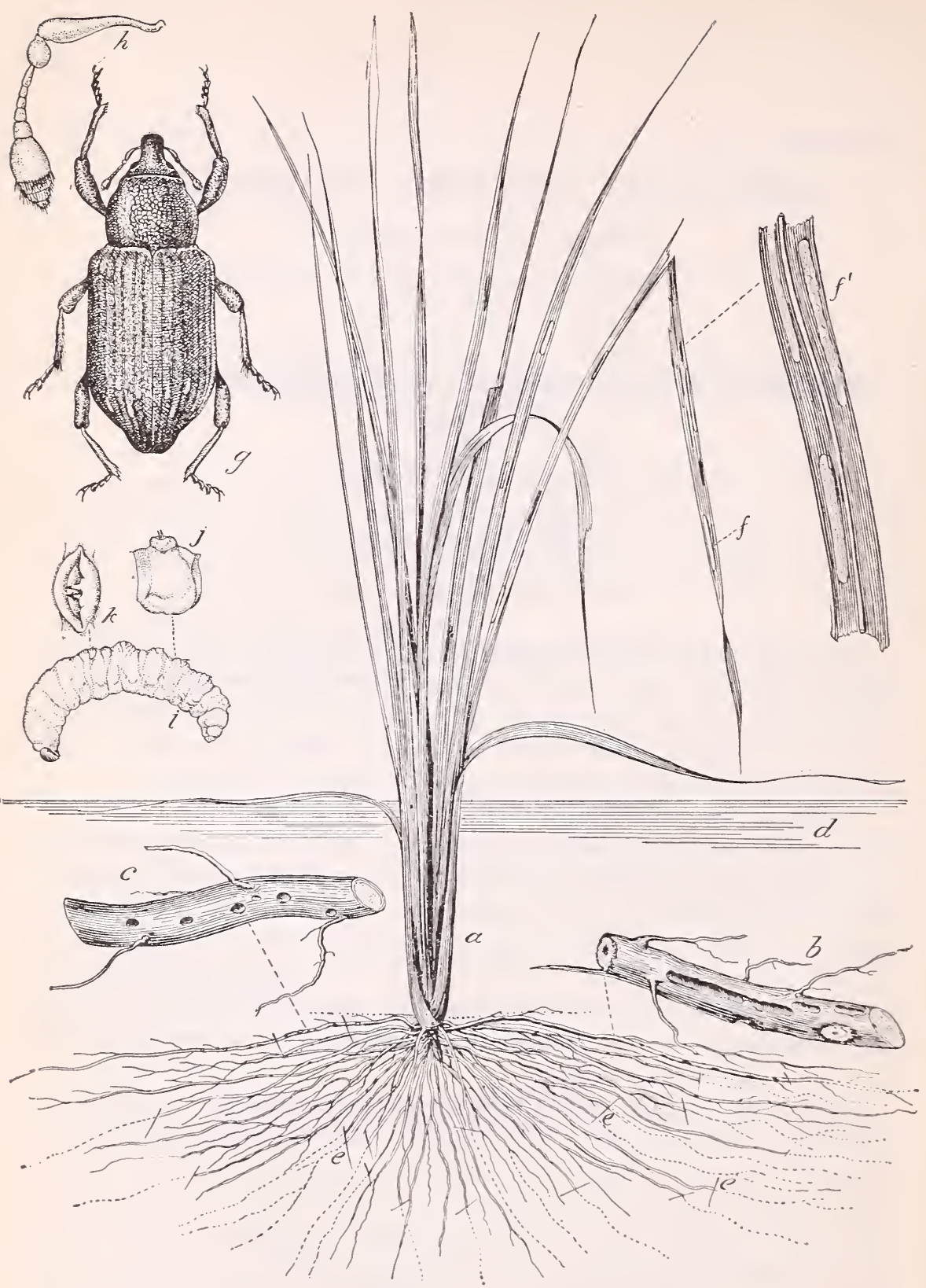

Fig. 1.-The rice water-weevil (Lissorhoptrus simplex) : a, Rice plant showing injuries; $b$, larval scars on section of root; $c$, section of rootlet showing feeding scars: $d$, water line; $e, e, c$, roots severed by larrie; $f$, injured leaf; $f^{\prime}$, enlarged section of injured leaf ; $g$, adult beetle, dorsal view, mueh enlarged; $h$, antenna of beetle, more enlarged; $i$, larva, side view, much enlarged: $j$, enlarged segment of larva, lateral view; $k$, dorsal structure of larva. (Original.) 
The recent work of the bureau on the rice water-weevil was begun in 1910 by Mr. C. E. Hood, working under the direction of Mr. D. L. Van Dine. The present writer began work on the problem in 1911. In this circular many notes made by Mr. Hood are incorporated.

The object of this paper is to give as much practical information as is now available about the weevil and measures for its control in order that rice growers may make proper efforts in fighting the pest and secure larger crops. The cooperative facilities afforded by the Agricultural Experiment Station of Louisiana, through Prof. IV. R. Dodson, director, in providing accommodations at the State Rice Station, Crowley, La., and allowing free use of the unpublished notes comprising a preliminary investigation of the rice water-weevil by Mr. Wilmon Newell, in 1909, deserve grateful acknowledgment.

HISTORICAL ACCOUNT AND DISTRIBUTION.

The weevil was originally described in 1831 as Bagous simplex by Thomas Say. It and another species of weevil were given the generic name of Lissorhoptrus by Dr. J. L. LeConte in 1876. LeConte and Horn have stated that the weevil commonly inhabits swampy places throughout the eastern part of the United States. Its northern range extends into the Lower Peninsula of Michigan, according to Hubbard and Schwarz, and Dury has recorded the species as being taken near Cincinnati, Ohio. It is also reported from New Jersey, Maryland, and the District of Columbia. Mr. E. A. Schwarz has concluded " that the genus Lissorhoptrus occurs all along the Atlantic coast (including the Gulf of Mexico), recurs along the Great Lakes, and is occasionally found inland."

As an injurious insect, the species first attracted the attention of rice farmers along the Savannah River in Georgia and South Carolina. In 1881 Dr. L. O. Howard visited a rice plantation known as "Proctor's," and owned by Col. John Screven, on the South Carolina side of the river, a short distance below Savannah, Ga., for the purpose of studying the insects affecting rice crops. An account of his observations, including notes on the rice water-weevil, was published in the report of the United States Commissioner of Agriculture for 1881 and 1882. But little adrance has been made in further knowledge of rice-crop insects up to the present investigation.

DESCRIPTIONS OF STAGES.

The adult.-The mature insect is a small, dark-gray weevil (fig. $1, g)$. The technical description by Mr. E. A. Schwarz in the account above mentioned is here quoted:

Lissorhoptrus simplex.-Imago: Average length from tip of thorax, $3 \mathrm{~mm}$. Oblong-oval, covered with large, dirt-colored scales, but usually entirely en- 
veloped in an argillaceous coating, which renders scales and sculpture irrecognizable. Rostrum stout, as long as head and thorax, subcylindrical, densely rugosely punctulate, neither sulcate nor carinate: head densely punctulate. Thorax as long as wide. constricted anteriorly, lateral lobes well dereloped, sides moderately rounded, base truncate, a finely impressed median line, surface densely rugosely punctate, sides at middle with a shallow transrerse impression. Elytra much wider at base than thorax and about twice as long; humeri oblique, strongly declirous at apex, punctate-striate, interstices wide, subconvex, 3d and 5th more prominent at declivity than the rest. Prosternum flattened, transversely impressed in front of coxæ; abdomen coarsely punctate. Tibiæ somewhat curred, armed with a strong terminal hook; tarsi narrow, third joint not emarginate; claws slender, approximate.

Very little difference exists between the sexes. The females usually have a slightly larger body than the males, and are often more distinctly marked with a black area on the back. The marks of coloration, howerer, show more plainly on live moistened specimens in the field than on dry examples either alive or dead. According to $\mathbf{M r}$. IT. D. Pierce, a secondary sexual character is presented by the configuration of the scrobe on the beak. He has determined that the scrobe of the female is slightly curved, but in the male it is practically straight. These fine distinctions are difficult to make out with certainty on account of the natural currature of the beak.

The pupa.-No example of the pupa fit for description has yet been obtained, as it is very soft and any slight pressure or touch that is exerted in attempting to remove one from the mud crushes or distorts it.

The egg.-All attempts to secure deposited eggs hare afforded only partial results. For purposes of description dependence must at present be placed upon the appearance of eggs obtained by dissection of gravid female weevils. Mr. Wilmon Newell, in presenting a description based upon such obserrations, has stated that the egg is pure white, cylindrical and slightly curved in form, and has a length about five times the diameter. It is barely visible to the naked eye.

LIFE HISTORY.

SEMIAQUATIC H.ABITS.

Water is an element in which the weeril delights. It swims readily on or beneath the surface, and it feeds. rests. and mates almost as frequently in the water as above it. To determine how long the adults can live under water, Mr. C. E. Hood conducted a test in which one weevil died after passing the first $2+1$ hours of submersion, but two did not die until after being kept submerged for fully 96 hours. The weevil does not carry a bubble of air for breathing purposes when it goes below the surface, although tiny globules of air are apt to adhere to parts of the body. Writhout water, the insect can not breed. The eggs are probably deposited on roots under water or in mud, and the 
larra, and doubtless also the pupa, require a bed of saturated earth in which to live. Tet conditions of soil with suitable regetation appear to be necessary for the development of all the stages.

\section{FOOD PLANTS.}

The semiaquatic life of the insect demands that its proper food plants be adapted for growing in moist situations or entirely in water. The adult weeril itself is not disposed to feed on any plant unless the roots are at least partially covered with water or soft mud. In South Carolina Dr. Howard observed weerils feeding on "Sagittaria, Scirpus, Cyperus. Nymphæa, and Nuphar"-plants commonly known as arrowhead, bulrush, galingale, water lily, and spatter-dock. Besides these, he reported wild rice (Zizania aquatica) as well as cultirated rice (Oryza sativa). One specimen has been collected as a visitor on Baptisia at Victoria, Tex. All positive records of additional food plants refer entirely to grasses and they are the result of observations that were mostly made in Louisiana. Mr. Hood has reported some of the Louisiana grasses by the common names of "bull grass" and "nigger"s wool," which grew at Crowley. "Hurrah grass" was recorded by Mr. D. L. Tan Dine at Matagorda, Tex. Adult weerils fed on the leares of these undetermined grasses and the larræ were found on the roots of the first, which was identified by the writer as a Paspalum and was said to have been introduced into the country. "Bull grass" is a rery common term in the section and refers to sereral species of grasses.

The occurrence of weevils on Walter's swale grass (Paspatum membranaceum) was first observed by Mr. Nerrell at Lake Arthur, La. Thile similar observations have been made by the writer at Crowles, La., and Pine Bluff, Ark., the finding of larræ on the roots of the grass at Crowley presented complete evidence of the true host relationship of the plant. This fact. howerer, may have been discorered by Mr. Newell two years previously at the same place where he found larvæ infesting the roots of a stocky Paspalum, which he was inclined to regard as another species.

Also during the season of 1911. at Crowles, La., the writer found two other species of grass which attracted the weerils from the nearest rice plants. One of these was Bermuda grass (Capriola dactylon). It grew on a levee in a rice field which had become partly orerflowed with the flood water. As an attempt had been made to grow it on the land previous to the rice crop, its occurrence under flooded conditions was exceptional: and no larræ were found attacking the roots. It can not be considered as a proper host plant. In the other case, a bunch of " water crab grass." undoubtedly a species of Syntherisma, was making a desperate struggle for existence 
within a flooded rice field. Having evidently started into growth before the field became irrigated, this crab grass was able to live in a depth of about 6 inches of water. Not only were the leares sererely fed upon by weevils, but the roots were attacked by larræ.

APPEARANCE OF ADULTS IN RICE FIELDS.

Since the growing of rice offers special inducements for the breeding of the weevil, due to the attraction of the plants and the wet conditions which they demand for growth, rice has become the farorite food plant of the insect. Directly after the rice fields are flooded the weevils appear and commence feeding on the leaves of the young plants. In southern Louisiana, where much of the water is supplied by canals, the irrigation of rice fields usually begins in the first week of May, but the time of turning on water in different fields is often later, the flooding sometimes not being done until in July to accord with late planting. Where water is pumped onto the fields, a steady flow must be maintained for sereral days before any large area of land can be inundated. The flooding of fields in Arkansas is not generally effected earlier than the middle of June.

By following the application of water in every field the weevils gather most numerously on plants that stand in the depressions and lower portions having the deepest flood. Mr. Hood has counted as many as 18 weevils on a stool and 12 on a single plant. An arerage of at least 1 weevil to every 5 or 6 plants in one field has been reckoned by Mr. Newell. Some inclination to a void direct sunlight during days of hot weather is shown by the weevils, as they seem to prefer positions in the shade of the plants and under the surface of the water.

They are rather sluggish except when swimming and are disposed to feign death if taken in the hand. They show no inclination to fly during the day and even refuse to expand the wings on being tossed into the air. Passage between separate plants is accomplished in the daytime by swimming. That they can fly for long distances, however, is clearly proven by their attraction to artificial lights at night. This propensity will be more fully discussed with reference to methods of control. Invasion of fields must therefore be consummated at night.

NATURE OF ATTACKS BI ADULTS.

Rice is attacked in the same manner as other similar host plants and the effects of the feeding by the adults are soon manifested by the appearance of scars on the leares. (Fig. 1,f.) In the act of feeding, the weevil braces its body firmly on the upper side of a leaf, and moving slowly forward in a longitudinal direction either up or down the blade, it chews out the epidermis and produces a scar, leaving 
the underside uneaten. These scars are very narrow, being in fact no wider than the spread of the mandibles, but they vary in length from a small fraction of an inch to more than 2 inches, depending on the time in which the insect engages in feeding. When the thin underside dries within the scar, it splits and forms an open groove throughout the injured spacé. The leaves suffer no serious ill effects from being fed upon unless the scars become numerous enough to cause wilting and dying. Adults prefer tender young plants rather than the coarser strong growth.

MATING AND OVIPOSITION.

Throughout the period in which the weevils remain in evidence, mating takes place on nearly all occasions when a male and female happen to meet, and this usually occurs on a leaf. The gravid females crawl down the stems of the plants and evidently deposit their eggs singly in a puncture that is first gnawed in a root. Mr. Newell has mentioned that he has seen adult weevils which he believed to be females make punctures on the stems below the water line. Mr. Hood and the writer have watched the operations of females when they apparently undertook to oviposit on rice roots within glass tubes. Each weevil thus obserred deliberately sought out a place on a root and ate into it for about a minute. Then she reversed her body, gripped tightly, and pressed the tip of the abdomen over the hole which she had eaten out. Mr. Hood has recorded that he saw the ovipositor in the form of a brown tubular organ inserted into the hole. In this case the weeril remained in position without any apparent movement for 50 seconds before the ovipositor was withdrawn. The writer has not been able to see the ovipositor extended nor to detect an egg with certainty. The weevil may climb up above the water after each operation and rest for a long or short period, or continue her actions among the roots for a while. One weevil stayed among the roots for 45 minutes.

The device that was designed and used by the writer for observing the method of oviposition by the weevils is illustrated in figure 2. In its construction a long lamp chimney was placed upright in a sancer and cemented at the base with plaster of Paris. A wire support with the top bent into a loop of the proper size for steadying a closed-bottom glass tube, one with an inch diameter being used to hold the roots of a young rice plant in water, was first placed in the center of the saucer. The lower end of the support was also bent in a spiral to secure firmness after being set in the plaster. By means of a string tied to the upper part of the tube, it could be lowered through the top of the chimney into a standing position within the wire loop and also remored to permit close inspection of roots and insects inside of it whenever desired.

$40998^{\circ}$ - Cir. 152-12-2 
NATURE OF ATTACKS BY LARTE.

Mr. Hood has stated that the larvæ are first found in the rice fields from one to three weeks after the turning on of the water, the

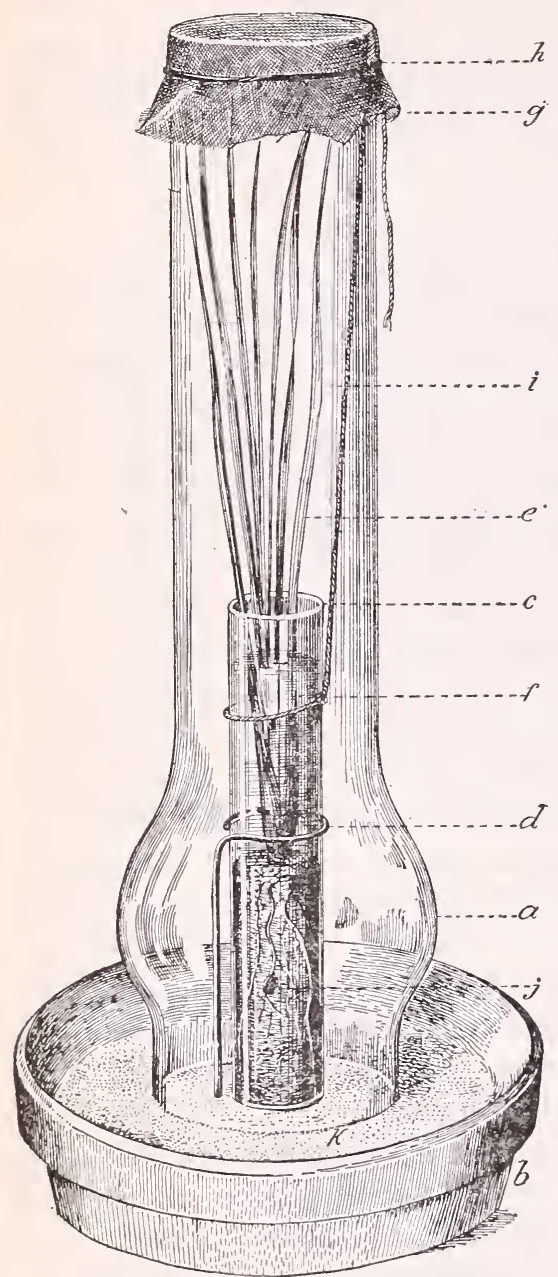

Fig. 2.-Lamp-chimney cage for rearing and observing the rice water-weevil: $a$, Glass lamp chimney; $b$, vessel containing plaster of Paris; $c$, glass tube; $d$, wire support; $e$, rice plant; $f$, string lift; $g$, gauze; $h$, rubber band; $i, j$, beetles feeding. (Original.) time of their inception varying with the weather. Hot weather accelerates their development. The young larvæ, which have doubtless hatched from eggs laid in the roots, begin to feed on them, and in course of time as the larvæ increase in size they devour or sever large portions of the root system. They have been known to eat holes in large rice roots and burrow into them. Mr. IV. D. Pierce, at Beaumont, Tex., in 1904, found vigorous larvæ consuming the entire interior of the roots. Figure 1 , $c$, gives a representation of six feeding holes made at a distance not more than one-fourth of an inch apart as Mr. Hood riewed them. The common methods of attack result in a pruning of the roots, after which the severed portions rot and the remaining parts are further marred with feeding scars. At this stage the hold of the plant upon the soil is greatly weakened and it can be pulled from the ground with ease. In some instances on record the root systems were entirely destroyed and the rice plants floated in the water.

The injuries done by the larra first cause the leaves of the rice plants to turn a pale yellow and droop, the lower blades often resting on the water. With severe attacks some of the leaves may die. These effects in the fields become most pronounced on plants growing in tepressions and low portions of the land into which the water first flowed and where it 
stands deepest. As previously mentioned, such places are most attractive to the adults. Where the adults occur most numerously the larvæ must be expected to follow in great number. In consequence the severity of the larval infestations is shown by a yellow cast of the leaves extending in broad streaks along dead furrows, while spots and areas of yellowish plants also become visibly apparent within the hollows and sinks of the land. These signs of injury have appeared in fields after 20 days of flooding, but ordinarily the larvæ do not become numerous enough to cause much damage until the water has stood for at least a month.

If many of the roots are cut off from a plant (fig. 1,e), its growth is stunted, but as the growing rice plant possesses a strong vital power new roots are put out to replace the ones destroyed, and on the cessation of attacks the injured plant revives, or is said to "recover," and makes a belated growth, usually resulting in late heading. Much of the unequal growth of the plants in the fields, as well as the irregular maturity of heads, is accountable to the detrimental effects of the larval attacks. Harvesting must necessarily be delayed until all the heads are ripe, thus involving the risk of loss to the normal yield from storms or other causes.

Furthermore, the attacks on the roots of tender young plants prevent proper stooling or production of stems. In comparison with normal plants, often less than half as many stems grow from a stool that has suffered damage. Shortage of heads is therefore caused by the failure of badly injured plants to produce a full quota of stems. The fact that the larvæ are largely responsible for a great deficiency of yield in this respect will impress a comprehension of the amount of loss caused by the insect.

DEVELOPMENT OF STAGES.

The length of time required for the development of the weevil from a freshly laid egg has been estimated by Mr. Hood to be about 10 weeks. Judging from the first occurrence of larvæ in fields after 1 to 3 weeks of flooding, a period not to exceed 10 days would probably be ample time for an egg to hatch subsequent to deposition. Development is hastened with the advance of hot weather when the water and soil become warm. Usually not until about six or seven weeks after flooding do many of the larvæ attain full growth and appear ready for pupation, although pupæ have been found in a field that at the time had been irrigated for only five weeks. In preparation for the pupal stage the larva forms a cell in the mud among the roots or at the tip of one, and Mr. Hood has asserted that the pupa passes two or three weeks before it matures and the emergence of the adult takes place. 
With the aim of working out the details of derelopment of the larval and pupal stages, a number of larræ were placed on the roots of young rice plants, each of which was set in water within a glass tube, the tubes being simply stood in a holder. Attempts to carry through the development of pupæ from larvæ when subjected to constant exposure to light proved only partially successful, but better progress, although still lacking completeness, was made after shielding the tubes from light and supplying a small amount of earth with the roots and water.

SEASONAL HISTORY AND GENERATIONS.

Adults as well as partially and full grown larvæ, and also without doubt the pupæ, occur in many fields up to the time of draining for harvest. With late crops in the coast region, howerer, and in the fields of Arkansas on account of the difference of the season in that State, the number of weevils in all these stages diminishes about the time when the plants begin to head in the latter part of August. Weevils found in fields after the drawing off of water to permit harresting are apt to be freshly emerged indiriduals of a new generation. From a collection of infested roots obtained by Mr. Pierce at Beaumont, Tex., June 28, 1904, adults emerged as early as July 2 following. In case such early emerged weevils breed at once, they have a chance to produce a second generation in a season, provided they find late flooded fields or suitable water holes. At Stuttgart, Ark., on September 12, Mr. Hood found roots of rice infested by a few larra which he regarded as representatives of a second generation. The last larva found by the writer during his stay at Crowley, La., was taken September 25. While the weerils that emerge in July possibly lay eggs for a second generation, the species is principally propagated in one rearly generation.

In the spring, before many of the rice fields were flooded, Mr. Hood collected adults on grasses and red rice growing in ditches and other places containing water. Since the weevils have not been known to breed in such places until the soil and water become sufficiently warm, at which time the flooding of rice fields is well under war, the deduction is made that low temperatures up to this time exert a restrictive influence upon breeding.

Examination of roots of red rice and other plants growing in a constantly flooded ditch at Crowley. La., on October 3, failed to disclose any evidences of infestation at the time. These results show conclusively that the weevil does not breed at this time of year even in most farorable situations. Not only were the adults absent, but the lack of feeding scars on the leaves denoted that they had not visited there for some time. 
The fact that adults live throughout the greater part of the season has been demonstrated several times. In an experiment with specimens collected at Mackay, Tex., April 5, 1904, Mr. W. W. Yothers succeeded in keeping the weevils alive by furnishing grass for food until after the middle of July. Weevils confined on rice plants by Mr. Hood at Crowley, La., July 18, lived later than the middle of September, and the writer has made a corresponding record.covering a period from July 11 to September 21.

The common absence if not scarcity of fresh signs of feeding by adults late in the season or at the time when the new generation of weevils is expected to emerge throws much doubt on the question of their taking any food then. At least they do not remain long on the plants, and the few feeding scars that may appear to have originated at the time are likely produced by lingering adults of the old generation. A yearly overlapping of generations in the adult stage evidently occurs. Few specimens that might be regarded as freshly emerged weevils have been found in the fields. These were taken by Mr. Hood, hiding in the cracks of the ground after the water had been drained from the field for harvesting. Possibly some of these weevils stray to electric lights at night, my last capture of a weevil being made on the night of September 20. If a new generation of weevils occurs no evidence of it has been found. The question is, What becomes of them until they go into hibernation?

\section{HIBERNATION. ${ }^{1}$}

During the fall and water of $1910 \mathrm{Mr}$. Hood made examinations of various places which might serve as hibernating quarters. The materials examined included rice stubble, loose dirt in the fields, strawstacks (both old and new), grass and other regetable matter along levees, and Spanish moss. No weevils were found hibernating except in the Spanish moss, which, however, afforded an excellent shelter, as the following tabulated observations made at Crowley, La., will show :

Observations on the places of hibernation of the rice water-weevil.

\begin{tabular}{|c|c|c|c|c|c|}
\hline Date of examination. & $\begin{array}{c}\text { Moss } \\
\text { examined. }\end{array}$ & $\begin{array}{c}\text { Distance } \\
\text { from } \\
\text { nearest } \\
\text { rice field. }\end{array}$ & $\begin{array}{l}\text { Height } \\
\text { above } \\
\text { ground. }\end{array}$ & $\begin{array}{l}\text { Number } \\
\text { of weevils } \\
\text { found. }\end{array}$ & $\begin{array}{c}\text { Estimated } \\
\text { number of } \\
\text { weevils } \\
\text { per ton } \\
\text { of moss. }\end{array}$ \\
\hline 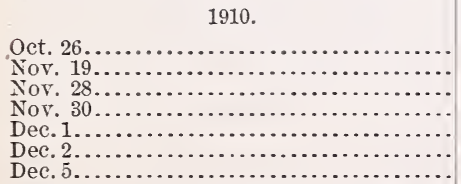 & $\begin{array}{r}\text { Pounds. } \\
1 \\
1 \frac{1}{2} \\
1 \frac{5}{8} \\
1 \frac{3}{8} \\
1 \frac{1}{2} \\
1 \frac{1}{2} \\
1 \frac{5}{8}\end{array}$ & $\begin{array}{l}\text { Hile. } \\
\begin{array}{l}\left({ }^{2}\right) \\
0.25 \\
.38 \\
.50 \\
.50 \\
.25 \\
.25\end{array}\end{array}$ & $\begin{array}{r}\text { Feet. } \\
6 \\
10 \\
6 \\
6 \\
6 \\
6 \\
6\end{array}$ & $\begin{array}{r}18 \\
21 \\
4 \\
1 \\
2 \\
45 \\
28\end{array}$ & $\begin{array}{r}36,000 \\
28,000 \\
4,920 \\
1,454 \\
2,666 \\
60,000 \\
34,460\end{array}$ \\
\hline
\end{tabular}

1 With the exception of a few remarks, all of the notes on hibernation of the weevils must be credited to Mr. Hood, who has made the most extensive investigations in regard to the subject.

2300 yards $(0.17$ mile $)$. 
As indicated by the preceding table, sereral thousand weerils may hibernate in the moss on a single tree. The appearance of large numbers of weevils in rice fields when they are first flooded has led to the opinion that the pest completes one generation on host plants other than rice before this time. But as already pointed out, no eridence has been secured that will sustain this view. Abundance of the weerils is probably due to their successful survival through the winter and emergence from hibernation.

One reference in literature mentions the occurrence of adults "in wintertime under old leaves and other shelter in drier places near the swamps." The finding of one adult in litter beneath rich stubble is recorded by Mr. D. L. Tan Dine as the result of searching for half of a day at Stewart, Tex., on October 2S, 1909. Entrance into hibernation is probably not begun much before the time when the nights are cold enough for frost. Not a single weeril could be found by the writer in a collection of Spanish moss obtained on September 29, at Crowley, La., and in the preceding spring after the first weevils appeared Mr. Hood was unable to find any specimens remaining in the moss.

\section{NATURAL ENEMIES.}

Besides birds no enemy is known to feed on the mature weevils, although the snakes and frogs which frequent the fields probably do so. Bird droppings found by Mr. Hood in a rice field at Stuttgart. Ark., on September 12 consisted largely of insect remains, those of the rice water-weeril being the most abundant. Howerer, two perfect specimens of the weevil were removed from the droppings and one was found to be alive. According to records in the Biological Survey, this weeril is eaten by the long-billed marsh wren (Telmatodytes palustris) and the mallard duck (Anas platyrhynchos).

Owing to their concealment in mud the larra and pupa are secure from enemies. When infested roots are pulled for examination and larve are washed out any minnows that happen to be present in the water will greedily snap the floating bodies. Predaceous larra of water beetles. which also abound in flooded fields, struggle with one another for possession of a weevil larva. If these predators and the several kinds of rapacious water bugs were adapted for burrowing in the mud and reaching the rice roots, they would be very efficient destroyers of both weevil larre and pupe. But their habit of hunting in the open spaces of water renders them of little or no service against the weevil.

METIOLS OF CONTROL.

DRAINING OF THE FIELDS.

As pointed out in the study of the life history, the existence of the larve and likewise the pupx depends upon a saturation of the soil. 
If the soil dries out after the larvæ have made an advance in growth, they soon die. The practice of draining fields and allowing them to dry enough to cause the death of the larræ was first proposed in 1881 by Col. John Screven, a rice planter in South Carolina, and was indorsed by Dr. Howard after his investigation in the field in 1881. Some of the rice growers in Louisiana and Texas have reported good results from periods of draining, while others have claimed that the plants suffered more from being deprived of water than from attacks. Many growers therefore adrocate deep flooding of fields as the proper treatment of rice when infested by the weevil larvæ.

Different results of draining are mainly accountable to the extent of damage done by the larræ at the time of releasing the water. When the roots hare been but slightly or not yet severely attacked, draining seems to result very effectively in most cases by the reduction of the number of larræ to a minimum. Effectiveness depends on the length of time that plants can stand without water and not suffer from the want of it. Plants that have a fair hold of roots show no ill effects of drying spells lasting from 5 to 10 days without rain. In case of heavy rain, drying should be carried on for some days longer or until the surface of the ground forms a dry crust and begins to crack. This stage of drying has been found very effective in causing the death of larvæ, and the ground has still retained sufficient moisture below the surface to stistain the plants that possessed a large proportion of roots.

On the other hand, when roots hare become severely pruned, the plants are unable to endure draining without being further impaired. Instead, they need a plentiful supply of water in order that new roots can be put out and growth resumed. The value of draining is dependent upon the enforcement of the practice at the proper time, which the grower can easily determine by making examinations of the roots. Many growers object to draining on account of the waste of water and the risk or difficulty of getting fields promptly flooded again. If fields were so arranged that water could be turned from one to another in succession or from early to late plantings, most of the water could be utilized and the saving in the cost of pumping, where this means of supply is employed, would be an item of consideration. Other benefits arising from changes of water will be mentioned later. Continuance of flooding to enable plants to overcome injury by larræ, instead of taking steps to destroy the weevils, will, as Mr. Newell has inferred, probably lead to a regular increase of the number of weevils until the point is reached where the insect will make profitable rice culture impossible. Constant or extra flooding does not in the least inconvenience the larvæ, but makes conditions even more farorable for them. Being the most practical method of controlling the reevils, draining of fields is therefore highly important. 
RESELTS OF DRAINING.

Conclusive observations upon tests of draining conducted by the writer or under his instructions during the season of 1911 are presented in the following statements.

At Crowley. La., on June 9, a rice grower drained some parts of his field of early planted Honduras rice in which fully one-fifth of the plants, then at a height of 15 to $1 \mathrm{~s}$ inches, showed yellow blades. The roots had been rather sererely pruned, but enough remained together with newly grown ones to permit draining with safety. As many as six and seren larræ infested the roots of a stool. Reflooding was effected June 19, after a period of drying which had lasted nearly 10 days. Quite a noticeable difference existed between the drained and undrained rice on July 21. The plants in the drained areas had nearly all headed out uniformly, while most of the undrained rice was behind in growth, either not having headed or having heads just formed and blooming. Regarding recorery, the owner said that the plants which grew in the fresh water after reflooding soon lost their yellow color and took on a rigorous growth of healthy green, but in the undrained parts with standing water the plants recorered much more slowly. At harvest time the owner estimated his best yield on land that had been drained to check the weeril larræ.

In the field of another grower, however, results were not so successful. These small young plants were not injured badly and showed only incipient spots and streaks of weak yellow color. This was a variety of Japan rice. The field was drained May 29 and reflooded June 8, giving a drying of 10 days. One week after reflooding the plants had taken on a fresh green color, and the infestation of the most injured roots had been reduced to a minimum, as shown by the nearly normal growth. Owing evidently to a second infestation, during which no draining was done, an irregular belated growth was displayed at heading time. Whether the outcome might have been worse without any draining can only be surmised.

Acting under a cooperative agreement, Mr. C. G. Haskell reported some very important results of his examinations at Almyra, Ark. On draining a field July 20 he found 25 larre on the roots of 25 stools. On flooding the field July 28 he found only two larre on the same number of roots. The result was accomplished by eight days of draining and drying. A stool usually produced five stalks or stems. By calculating percentages of infestation according to the number of stalks the draining must have reduced the proportion of larve from 20 per cent to 1.6 per cent.

Again. on draining a field July 2.5 Mr. Haskell found 50 larra on the roots of 2.5 stools, but on reflooding the field July 31 he found no more than 9 larve per 2.5 stools. The draining and drying therefore 
lasted six days, and calculating on a besis of fire stalks to a stool the infestation was reduced from 40 to $7.2 \mathrm{p}$ pr cent. The writer's own examination of this rice on August 1, the serond day of reflooding, gare substantial evidence of the reduction of larra in corresponding numbers, the count resulting in 3 larvæ on the roots of 40 stalks.

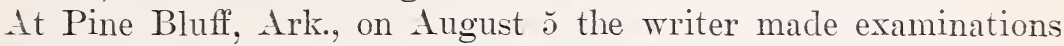
in a rice field that had been drained for fire days. On the roots of 105 stalks only nine larvæ were found alive. The infestation therefore amounted to approximately 9 per cent. The owner stated that before draining two and three larræ occurred on a stool. Calculating five stalks per stool, the infestation then could not have been less than $33 \frac{1}{3}$ per cent. In some places the ground was still saturated, but most of it was stiff mud. That the draining really caused a reduction in the number of larræ by death was evidenced by the finding of two dead ones, and some of the live ones seemed weak as if about ready to die. Not many roots were badly cut and the draining began at an opportune time. The pumping of water on this field was resumed August 8, but it was not wholly flooded until a few days later. The drying covered seven days at least. No rain fell during this time, and the ground had begun to crack from drying. The results were considered rery beneficial, as the larræ caused no further trouble and the rice headed out splendidly.

EFFECTS OF RUNNING WATER.

Direct observations, as well as the testimony of growers, hare brought out the fact that rice growing in running water suffer's little from weevil attacks. In these cases, howerer, no considerable area has yet been seen in which the water flowed with any perceptible current. To maintain a distinct moving flood over a large field would require an immense supply of water. The instances that have been observed were confined to spots or small plats corered by the inflow of water from a canal or ditch. In spreading onto a field from an inlet the current soon loses force and any low temperature. Where a cool flow of water is pumped from a well directly onto a field the low temperature seems to exert a controlling factor against infestaticn. But these cases are rare, because the rice demands warm temperatures for vigorous growth, and the sun heat greatly restricts the cool area.

EFFECTS OF DEEP AND SHALLOW FLOODING AND STAGNATION.

Deep water and stagnant water greatly faror derelopment of weevils. As already pointed out, rice in spots or areas of deep flooding is most sererely attacked. Severity of attacks is especially 
marked in shallow water almost as much as in deep water when either becomes stagnant. In a field that had receired only a scant supply of water, which in fact merely filled the low places although keeping all of the ground soaked, very few larræ could be found. Most of these larræe occurred on roots of weak plants in the pools, while the best growth stood out of water and was scarcely attacked at all. Soaking instead of flooding appeared to result rery beneficially, not only controlling infestation but inducing prime growth of plants at least past the stage of stooling when the coarse leaves offer little attraction to the reevils.

EFFECTS OF EARLY, DELAYED, AND LATE FLOODING.

Rice in different fields that were first flooded at rarious times corering a seasonal range of dates in accordance with the planting and sprouting has in due course been found subjected to the same degree of infestation. No advantage can be gained against the weeril by choosing any particular time for flooding that will still be suitable for the needs of the plants. An attempt to delay full flooding by a gradual soaking of fields in order that the plants might attain a strong growth and be able to withstand or escape attacks after deep water was applied met with interference from heary rainfalls which flooded the fields, and the owner then saved the water. The probable effectireness of soaking is indicated by the case of accidental shortage of water, as mentioned in the preceding subject.

EFFECTS OF ALTERNATE FLOODING AND DRYING.

At Crowley, La., on June 28, inspection was made of a field of rice that had been allowed to dry out from stoppage of water supply on two occasions, one lasting six days and the other four days. The occurrence of larvæ was limited principally to the most hearily flooded parts, and the roots of the plants were not badly injured. The comparative scarcity of the larre throughout the field was attributed to the effects of the two intervals of drying, and the rice escaped much danger from attacks.

At Almyra, Ark., on August 1, other observations were made on a field where scarcity of water had caused alternate periods of drying. Water had been supplied but little more than half of the time since first flooding. though the ground had been generally kept damp with the addition of rainfall. No larve were found on the roots of this rice, and only a few weevils occurred on weak plants near the edges of the field. The plants exhibited a high, vigorous. and fairly healthy growth. the lack of enough water having eviclently resulted in a yellow tinge of the leaves, which, however. promised to be 
speedily overcome owing to flooding rains. The crop eventually produced an excellent yield.

USE OF FERTILIZERS AND APPLICATION OF LIME.

In an experiment to determine whether the use of fertilizers and application of lime would serve as a check on weevil infestation, plats for growing rice were prepared at Crowley, La., as shown by the accompanying diagram, which also gives the results of examinations on July 8. The whole field was flooded equally to an average depth of 6 inches. The arrangement and treatment of the plats and status of infestation are outlined as follows:

\begin{tabular}{|c|c|c|c|}
\hline & Unlimed. & Unlimed. & $\begin{array}{l}\text { Limed, } 2,000 \\
\text { pounds per } \\
\text { acre. }\end{array}$ \\
\hline Checks............ & 5 larw per 25 stalks. & 1 larva. & 11 larvæ. \\
\hline 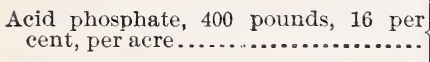 & 7 larvæ per 25 stalks. & 6 larvæ. & 6 larvæ. \\
\hline $\begin{array}{l}\text { Acid phosphate as above plus muriate } \\
\text { of potash, } 50 \text { pounds per acre ........ }\end{array}$ & 14 larve per 25 stalks. & 9 larvæ. & 7 larra. \\
\hline
\end{tabular}

Total proportionate number of larræ:

For the check plat. 17 , or $22 \frac{2}{3}$ per cent infestation.

For the phosphate plat 19 , or $25 \frac{1}{3}$ per cent infestation.

For the phosphate and potash plat_-_- 30, or 40 per cent infestation.

Calculating another way from the foregoing outline, the limed areas were found to have 24 larvæ compared with 16 larvæ in the unlimed areas of the same plat, while in the opposite plat 26 larvæ were taken on the roots of the same number of stalks.

No advantage in reducing or retarding infestation appeared to be shown through the application of fertilizers or lime to the soil, but rather the contrary effects are indicated, as the strip with double fertilization contained the most larvæ. Since the plant growth had responded in proportion to the degree of fertilization, the stimulated plants exhibited no signs of injury resulting in yellow appearance of leares except in the limed areas, which as a whole included the poorest growth on account of the severer pruning of the small root systems.

Further observations made at Midland, La., have led to the conclusion that fertilization does not prevent nor even hinder the propagation of larve, but the extra nourishment may assist the plants to overcome attacks. 
USE OF TRAP LIGHTS FOR ADULTS.

The appearance of adults at artificial lights at night has suggesterl the plan of placing lights in the fields and trapping the weevils which may be attracted. Great numbers of the weevils seek the electric lights of stores in the towns throughout regions where the insects abound. Ordinary lights in dwellings are sometimes frequented. At Crowley, La., more than a hundred weerils hare been collected within a few minutes on a single store window. They appear most numerously on warm dark nights, but, like many other insects, they do not fly to lights in any considerable number when the moon shines. Neither does the time of their flight seem to last long, for as soon as darkness has settled, most of them come in a rush, and only occasionally do stragglers show themselves later in the night. Their seasonal appearance begins from the 1st to the middle of April, and about the middle of August they become very scarce.

Tests of the efficiency of light as a practical means of attraction were conducted at Crowley. A portable acetylene outfit was used to furnish light, being operated near rice fields 1 mile from town. Some of the best results were as follows, the weerils being taken on a cloth screen that was provided for the purpose of inducing them to alight:

On the night of May 26, 1910, Mr. Tan Dine started the light at 8 o'clock and captured over 40 weerils in the first 15 minutes. Later the breeze increased and only strong flying insects came to the light.

Starting the light at 8 o'clock on July 19, after a day of heary rains, Mr. Hood collected 24 weevils in 45 minutes. But on the night of July 29, which was clear and warm with slight south breeze, he placed the light in the middle of a rice field and caught 125 weerils between 8 and 9 o'clock.

\section{SUGGESTIONS FOR PROTECTIVE TREATMIENT.}

POISONING ADULTS.

Then the weevils gather in particular portions of a rice field, as they often do along deeply flooded edges, dead furrows, and in spots, opportunities seem to be presented whereby the application of a food poison could be made effective. Is the weevils indulge in rather extensive feeding compared with their size, the poisoning of the plants would be apt to cause the death of great numbers of the adults that might feed upon the poisoned leares. The application of the poison should be made upon the first appearance of the insects before they have had much chance to oriposit. The poison must be selected with reference to its safety on the plants, and if in the form of a powder, it could be easily distributed by means of a dust gun, from 
which it might be spread for some distance by wind. Probably the only danger would be to live stock having access to the water the drinking of which would be a remote possibility.

CULTURAL MANAGEMENT.

Clean cultural management in dealing with the weevil as with other crop pests is advisable. By restricting the growth of the various grasses and other plants, particularly the objectionable red variety of rice, which grow along and within canals, ditches, and water holes, much advantage could be derived toward the suppression of the breeding of the weevils on the uncultivated host plants. Drainage of bayous, sinks, and water holes would doubtless be of great benefit for the control of the weevil alone.

Leveling of the surface of fields that are to be planted in rice and plowing in such a manner as to avoid dead furrows as much as possible would obviate many of the depressions which on being deeply flooded conduce to a high infestation of the plants in such places.

Finally, a thorough preparation of the soil before planting is to be recommended, in order that grass and weeds may be eradicated without the necessity of deep flooding for the purpose of drowning them. This will permit very shallow flooding with periods of draining or mere soaking of fields for the control of infestation and the betterment of the crops.

SUMMARY.

The rice water-weevil causes more damage to rice crops in the Southern States than any other insect affecting rice plants. When it is in the larval stage it commits severe injuries to rice plants by destroying the roots. Some harm is done by the adults in feeding on the leaves.

The insect chooses food plants that grow in wet places and it breeds only where it finds water. Eggs are evidently laid on roots in water or mud, under which conditions the larvæ hatch, feed, grow, and transform into pupæ, and finally the adults mature and emerge.

Two generations may possibly be produced in a season, but one generation seems to be the rule. Adults pass the winter in hibernation, appearing in spring and invading the rice fields.

The most practical means of controlling the weevil consists in the practice of draining and allowing infested rice fields to dry sufficiently at the proper time or before the attacks of larræ have greatly weakened the plants. Alternate flooding and drying, if carried out properly, will accomplish the same results. Very shallow flooding or soaking of fields restrains infestation. Fertilization assists the plants to overcome injury. 
Considerable numbers of weevils can be captured at lights and destroyed, and the possibility of poisoning them in fields needs to be put to the test. Cultural management should be directed with the view of enforcing every advantage against the weeril that will be consistent with the welfare of the crop.

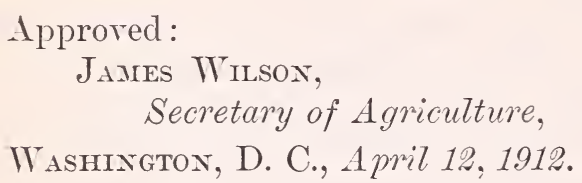

ADITIONAL COPIES of this publication may be procured from the SUPERINTENDOffice, Washington, D. C., at 5 cents per copy

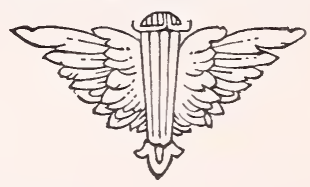





